\title{
When trade law meets public health evidence: the World Trade Organization and clove cigarettes
}

\author{
Holly Jarman, ${ }^{1}$ Judith Schmidt, ${ }^{2,3}$ Daniel B Rubin ${ }^{4} 5$
}

${ }^{1}$ Department of Health Management and Policy, University of Michigan, Ann Arbor, Michigan, USA

${ }^{2}$ University of Michigan Law School, Ann Arbor, Michigan, USA

${ }^{3}$ University of

Erlangen-Nuremberg, Germany

${ }^{4}$ Department of Health

Management and Policy, School of Public Health, University of Michigan, Ann Arbor, Michigan, USA

${ }^{5}$ University of Michigan Law School, Ann Arbor, Michigan, USA

\section{Correspondence to}

Holly Jarman, PhD, Department of Health Management and Policy, University of Michigan, 1415 Washington Heights, Ann Arbor, Michigan, USA; hjarman@umich.edu

Received 8 December 2011 Accepted 26 June 2012

Published Online First 15 June 2012

\section{ABSTRACT}

A recent trade dispute between the USA and Indonesia, overseen by the World Trade Organization, challenges piecemeal approaches to tobacco regulation.

\section{INTRODUCTION}

We report on an international trade dispute with important implications for tobacco regulation: the World Trade Organization's (WTO's) consideration of recent US legislation banning various flavoured cigarettes. ${ }^{1}$ While public health concerns pushed the US government to implement anti-tobacco regulations in 2009, Indonesia has challenged the ban as a trade barrier. The WTO's response sends a message to policymakers that will frustrate some advocates: the consistency of tobacco control regulations, and their relationship to clear public health evidence, are vital in determining the outcomes of trade disputes. The WTO's reasoning with clove cigarettes implies that the piecemeal, incremental approaches that characterise much tobacco regulation in the USA and elsewhere do not fit well with the core principles of the global trading system.

\section{INDONESIA VERSUS US (CLOVE CIGARETTES)}

The Clove Cigarettes case was brought by the Indonesian government against the US through the WTO's dispute settlement mechanism, a binding procedure in which panels of trade experts resolve inter-state disagreements.

The dispute focused on the US Family Smoking Prevention and Tobacco Control Act 2009 (FSPTC), which apart from attempting to give the US Food and Drug Administration (FDA) clear authority to regulate some tobacco products, prohibits constituents of or additives to cigarettes that are clove, cinnamon, candy, or fruit flavoured. Before the ban, Indonesia was a major exporter of clove-flavoured cigarettes to the US, and views the prohibition on their sale as a barrier to free trade.

The application of the FSPTC is narrow, as it only applies to cigarettes, loose tobacco, rolling papers and filters to be used in roll-your-own cigarettes. ${ }^{1}$ Indonesia claimed a violation based on a comparison of clove and (allegedly 'like') menthol cigarettes, but not of other tobacco products, and the WTO panel accepted the comparison Indonesia used. The FSPTC was already highly controversial within the US, particularly because it did not ban menthol cigarettes. This omission was arguably not based on public health evidence. Critics of the legislation point out that Philip Morris USA, the second largest manufacturer of menthol cigarettes in the US, played a key role in drafting the legislation. Public health scholarship shows that menthol cigarettes are perceived (incorrectly) by US consumers to be healthier than non-menthol cigarettes, and are marketed to specific demographic groups, particularly African-Americans, young people and women. $^{2}$ A recent FDA report ${ }^{3}$ argues that this incorrect perception leads more people to take up smoking, resulting in more deaths. As the majority of menthol cigarette smokers are African-American, neglecting to ban menthol was viewed by some as discrimination, treating African-Americans' health risks from smoking as less important.

The US government argued that the ban on clove cigarettes was motivated by health concerns, including that clove-flavoured cigarettes act as a 'gateway' product attracting children and young people to smoking. ${ }^{4}$ The House Energy and Commerce Committee, which drafted the law, reported that the ban was intended to reduce the number of children and adolescents who smoke cigarettes' by prohibiting 'the manufacture and sale of cigarettes with certain characterizing flavours that appeal to youth'.

In Clove Cigarettes, Indonesia argued that this claim was spurious, given that the FSPTC did not ban menthol cigarettes. In submissions to the WTO, Indonesia pointed out that while clove cigarettes, which are imported, were banned, menthol cigarettes, which are manufactured domestically, were not. ${ }^{4}$

\section{PANEL AND APPELLATE BODY FINDINGS}

A WTO panel, followed by the WTO's Appellate Body $(A B)$, considered Indonesia's case based on the WTO's Technical Barriers to Trade (TBT) Agreement, which provides rules for governments in setting the technical regulations and standards that can negatively affect trade. The panel's decision only applies to cigarettes, but that does not rule out the possibility that there may be another decision in the future that applies to other tobacco products. Although the WTO dispute settlement procedure does not employ formal precedent, in practice, future panels are highly likely to consider Clove Cigarettes when making decisions about tobacco products or public health regulations more generally. There are three key aspects of the panel and AB's conclusions that public health advocates, medical professionals and policymakers need to consider, outlined below.

\section{Public health goals are not systematically considered in WTO disputes}

In Clove Cigarettes, the panel and $A B$ only compared two products: (domestic) menthol 
cigarettes and (imported) clove cigarettes. Through this comparison, the panel and $\mathrm{AB}$ both determined that the ban on clove cigarettes discriminated against Indonesian imports. But they disagreed over the extent to which other issues, such as the health risks of each product, should be considered in reaching a decision.

The panel's determination that menthol and clove cigarettes were 'like' enough to form a good comparison was based in part on a review of public health evidence, confirming that clove and menthol cigarettes both appeal to youth, as well as a consideration of the goals of the legislation: above all, the aim of reducing youth smoking. The $\mathrm{AB}$ disagreed, stating that only the competitive relationship between the products was relevant in determining 'likeness'.

Instead, The $A B$ considered the regulatory purpose of this measure under a different criterion ('less favourable treatment'), where it required that a measure be based 'exclusively' on a legitimate regulatory distinction. Considering the various motives that can underlie a regulation in real life and the difficulties that can arise when evidence on this has to be presented, public health officials should not expect that trade tribunals will accept just any public health goal as sufficient.

Regulations do not have to be 'protectionist' to violate WTO rules The TBT requires states to afford goods from any other WTO member 'no less favourable' treatment than the 'like' goods of any other trading partner. From this perspective, the existence of a ban for a foreign product, but no ban for a similar, domestic product, looks suspiciously like protectionist discrimination against foreign firms in favour of domestic manufacturers. The panel found that the US had violated its commitments under the TBT because foreign producers fared worse than domestic ones under the FSPTC. ${ }^{4}$ The $\mathrm{AB}$ upheld this finding, although used different reasoning. ${ }^{6}$

But the Clove Cigarettes case is not a simple case of protectionism. Before the ban, clove cigarettes formed only a tiny share of the US market. There is not strong evidence that they were banned because of lobbying by tobacco companies. Neither did legislators particularly want US cigarettes to benefit to the detriment of foreign cigarettes; many wanted to ban all flavoured cigarettes, but made a very significant concession.

The $\mathrm{AB}$ found this concession sufficient for an Art. 2.1 TBT violation, ${ }^{7}$ meaning that the legislation did not have to be intentionally protectionist in order to be discriminatory. The panel and the $A B$ found that the reasons the US gave for prohibiting clove cigarettes while allowing menthol ones were not 'legitimate regulatory distinctions' under WTO rules. ${ }^{6}$

\section{Public health evidence can strongly influence the outcome of a WTO dispute}

The panel did not agree with Indonesia that the ban was 'more trade restrictive than necessary' (para 7.428 ) ${ }^{4}$ to achieve the aim of reducing youth smoking, meaning that although they thought the ban was discriminatory, they did not think it was arbitrarily restrictive. Indonesia claimed that there was not enough scientific evidence for banning clove cigarettes as dangerous to young people, and claimed that the US could have adopted less trade restrictive measures to keep young people from smoking, but the panel disagreed with both of these arguments.

Importantly, the panel based much of their reasoning on this point on a review of relevant public health evidence. The panel examined a range of evidence including WHO studies, the WHO Partial Guidelines for implementation of Articles 9 and 10 of the
WHO Framework Convention on Tobacco Control (FCTC), FDA Guidance, national surveys, journal articles and other reports submitted by the parties. The panel used their review to argue that young people are indeed attracted to all flavoured cigarettes as a way to start smoking. They found a 'growing consensus' among public health scholars in support of US policy, which 'reflects at least the majority view, and potentially the unanimous view' among public health researchers. ${ }^{4}$ They also refuted Indonesia's suggestion that the US could have adopted a less trade restrictive policy to achieve the same result, stating that there was not enough evidence that an alternative policy would have been equally effective.

Clove Cigarettes also tells us something important about the way that panels and states use international agreements to further their own arguments. The US and Indonesia both referred to the Framework Convention on Tobacco Control (FCTC) to support opposing positions, despite the fact that the US has not ratified, and Indonesia has not signed, the agreement. The panel referenced the FCTC in the same way as it would when using a dictionary or other source of factual evidence: to clarify what is meant by tobacco control ${ }^{4}$ and to reference the existence of international efforts to curb smoking. ${ }^{4}$ The panel report directly quotes the WHO Partial Guidelines in reference to added ingredients, including flavours that make tobacco products more attractive or palatable to consumers. ${ }^{4}$

\section{NEXT STEPS}

$\mathrm{AB}$ and modified panel reports are automatically adopted unless all 153 WTO member states collectively disagree. Their recommendations become binding on the WTO members party to the dispute. The Clove Cigarettes report was adopted on 24 April 2012, which means that the US is now obliged to bring its legislation 'into conformity with' the violated WTO law.

There are several options open to US policymakers. First, they could try to delay any changes in US law. WTO members can ask for a 'reasonable period of time' to comply, with the length of this period set by negotiating with the other parties or through formal arbitration. Second, the US could negotiate with Indonesia about compensating them with other trade concessions, but this tactic rarely proves successful. Third, the US could decide not to comply and accept the consequences. This might be a viable option if policymakers judge that the economic pain from any retaliatory trade barriers put in place by Indonesia would be economically and politically bearable. Finally, policymakers could decide to change US law. This could include moving to ban menthol cigarettes, repealing the ban on clove cigarettes, repealing the ban on all flavours, or enacting compromise reforms that would reframe the issue in favour of the US.

Given the current election campaign, the US administration might adopt a mixed strategy by obtaining a long implementation period, making minimal changes to the law and risking a compliance review while using political and diplomatic pressure on Indonesia to avoid the worst outcomes. But such a strategy only works for a powerful state like the US.

\section{IMPLICATIONS FOR TOBACCO CONTROL POLICY}

The WTO's ruling comes at a time when important questions are being asked about the relationship between public health evidence and international economic law. Trade and investment disputes over tobacco regulation are not going away, and multinational tobacco companies have frequently shown that they will pursue all available legal options. Opportunities for 
corporations to use law to challenge public health regulations are increasing, with more international agreements being signed that protect the rights of businesses investing or selling products abroad. Philip Morris, for example, is pursuing investment cases against the governments of Uruguay (limited product lines, mandated imagery) and Australia (plain packaging), and challenged Norway's visual display ban. Nor are state-led cases likely to diminish. The Ukraine and Honduras are currently challenging Australia's plain packaging legislation through the WTO dispute settlement mechanism, and several other states have expressed concerns about plain packaging policies in WTO meetings.

These challenges may make it harder for governments to maintain stable regulatory environments around tobacco products. The US administration has reacted to this legal uncertainty by proposing language to be inserted into the Trans Pacific Partnership (TPP) agreement, a trade and investment agreement being negotiated between the US and eight other states. This is a significant step, as any successfully negotiated text could be the model for future agreements.

The TPP negotiations have been strongly criticised for being secretive, and the draft text of the agreement is not publicly available. This secrecy makes it difficult to analyse the US proposal, but the Office of the US Trade Representative (USTR) intends the language to 'explicitly recognise the unique status of tobacco products from a health and regulatory perspective'. ${ }^{8}$ An exception would be inserted into the agreement supporting the ability of signatory governments to 'adopt regulations that impose origin-neutral, science-based restrictions on specific tobacco products/classes in order to safeguard public health' without breaking their commitments under the TPP. ${ }^{8}$

This raises many questions, but two are particularly important. First, a specific tobacco exception in the TBT may not have helped the US case much in Clove Cigarettes. The tobacco exception is intended to promote 'greater certainty that the provisions in the TPP will not be used in a manner that would prevent FDA from taking the sorts of incremental regulatory actions that are necessary to effectively implement the Tobacco Control Act' (emphasis added). ${ }^{8}$ But several current disputes, including Clove Cigarettes, concern primary legislation, not the regulation derived from it. ${ }^{9}$

Second, as we see from Clove Cigarettes, the requirement for regulations to be 'science based' is not a simple matter. Arguably, omitting to ban menthol cigarettes in the FSPTC was not an evidence-based decision, and this contributed to the WTO's negative ruling. However, the panel's review of public health studies led them to conclude that a ban, rather than some less restrictive measure, was appropriate in order to decrease youth smoking: that the measure adopted was in line with the legislation's stated objective.

A requirement to consider scientific evidence raises many realworld difficulties for tobacco control policies; in many political systems, the only means of passing tobacco control legislation is via bargaining between all interested parties, which means making at least some concessions to tobacco companies which do not align with the conclusions of public health research. We do not yet know how the text regarding scientific evidence will be structured. Whatever the model, it must be flexible enough to accommodate this political reality.

One way to do this is to strengthen the case for the FCTC, the Punta del Este Declaration, the Partial Guidelines and other current and future international health agreements to be considered as relevant standards in trade and investment cases with implications for public health. Governments and advocates must work together to continue to clarify the meaning of these texts in relation to trade and investment agreements, build diplomatic consensus around their importance, raise their visibility, and empower individual governments to use them as evidence in future cases.

We strongly recommend that broader global regulatory principles supporting population health, recognised as legitimate by the majority of state actors, need to be developed in order to inform adjudicators in future trade and investment disputes. ${ }^{10}$ The use of non-trade law to further arguments in trade disputes is controversial in legal circles, ${ }^{11}$ but should be openly discussed, and the possibility of using global health agreements to add context to cases should not be overlooked if we are to strengthen the impact of public health norms on decision making in trade and investment law.

Contributors $\mathrm{HJ}$ jointly formulated the research questions and design, conducted policy analysis, drafted the paper, revised the draft paper and acts as guarantor. JS jointly formulated the research questions and design, conducted legal analysis, drafted the paper and revised the draft paper. DBR jointly formulated the research questions and design, conducted legal analysis and revised the draft paper.

\section{Competing interests None.}

Provenance and peer review Not commissioned; externally peer reviewed.

\section{REFERENCES}

1. Family Smoking Prevention and Tobacco Control Act of 2009, Pub L No 111-21, 123 Stat. 1776. 2009. Section 101 (b)

2. Anderson SJ. Marketing of menthol cigarettes and consumer perceptions: a review of tobacco industry documents. Tob Control 2011;20:ii20-8. doi:10.1136/ tc. 2010.041939 .

3. Tobacco Products Scientific Advisory Committee. Menthol Cigarettes And Public Health: Review Of The Scientific Evidence And Recommendations. Washington DC: US Food and Drug Administration, 2011

4. World Trade Organization. United States-Measures affecting the Production and sale of clove cigarettes (WT/DS406/R), Panel Report of Sept. 2, 2011. http://www. wto.org/english/tratop e/dispu e/cases e/ds406 e.htm

5. H.R. Rep. No. 111-58, Pt. 1. Family Smoking Prevention And Tobacco Control Act of 2009. House Comm. on Energy and Commerce, 111th Cong., 1st Sess. 2009.

6. World Trade Organization. United states-Measures affecting the Production and sale of clove Cigarettes - Ab-2012-1-report of the Appellate Body. 2012.

7. World Trade Organization. Agreement on Technical Barriers to Trade. 1994. Art. 2.2.

8. Office of the US Trade Representative. TPP Tobacco Proposal. 2012. http:// www.ustr.gov/about-us/press-office/fact-sheets/2012/may/tpp-tobacco-proposal

9. McGrady B. Clarification of US proposal on tobacco in the TPP. O'Neill Institute for National and Global Health Law. 2012. http://www.oneillinstitutetradeblog.org/ clarification-of-us-proposal-on-tobacco-in-the-tpp/

10. Gostin LA. A proposal for a framework convention on global health. J Int Econ Law 2007;10:989-1008.

11. Voon TS, Mitchell AD. Implications of international investment law for tobacco flavouring regulation. J World Investment \& Trade 2011;12. 


\title{
TC When trade law meets public health evidence: the World Trade Organization and clove cigarettes
}

Holly Jarman, Judith Schmidt and Daniel B Rubin

Tob Control 2012 21: 596-598 originally published online July 21, 2012

doi: 10.1136/tobaccocontrol-2011-050376

Updated information and services can be found at:

http://tobaccocontrol.bmj.com/content/21/6/596

\begin{abstract}
These include:
References This article cites 2 articles, 2 of which you can access for free at: http://tobaccocontrol.bmj.com/content/21/6/596\#BIBL

Email alerting Receive free email alerts when new articles cite this article. Sign up in the service box at the top right corner of the online article.
\end{abstract}

\section{Notes}

To request permissions go to:

http://group.bmj.com/group/rights-licensing/permissions

To order reprints go to:

http://journals.bmj.com/cgi/reprintform

To subscribe to BMJ go to:

http://group.bmj.com/subscribe/ 